\title{
The Role of Media in Developing the Jordanian Community Awareness of Child Rights
}

\author{
Dr. Mohammad. M. Hussainat \\ Sociology Associate Professor, Department of Education and Social Sciences, Al Balqa \\ Applied University, Ajloun University College ,Jordan
}

Accepted: December 07, 2012 Published: January 28, 2013

Doi:10.5296/jsr.v4i1.3167ＵRL: http://dx.doi.org/10.5296/jsr.v4i1.3167

\begin{abstract}
The study not only explores how far the child's rights are practiced in Jordan, but it also identifies the roles and effects of parents, the media (radio, television ) and the degree of parent awareness of such rights. The study, consisting of eighteen -item researcher designed questionnaire involved a sample of (200) families in the governorate of Ajloun. The study showed there is a parent awareness of Jordanian child rights, but it indicated that the media kind (radio or television) has a statistically significant difference in the degree of the parents' awareness of child rights .
\end{abstract}

Keywords: Child Rights, Media, The Relationship Between The Media And Child Rights.

\section{Introduction}

All countries all over the world and their leaders including Jordan put the children rights and needs on the top of their world agenda in the world summit for children in 1990. They announced their assurance to be committed to funding, putting plans in order to improve children life and include this treaty they signed in their national legislations. Jordan has cooperated with governmental and non-governmental institutions to reinforce and protect child rights and caring to achieve the objectives included in the previous treaty . The political commitment by the sequenced governments to children rights urged the mass media in Jordan to follow up all new developments related to childhood .The Jordanian news agency, Petra has been focusing since 1998 on different domains of child life not only to spot the shortcomings and handle them properly, but to identify the public and private sectors contributions in enriching the child life to achieve the treaty objectives. Therefore, this study has come to investigate the role of Jordanian media in developing the awareness of child rights. 


\section{Problem of the Study}

The modern world has social, economic and environmental problems. Mass media has a significant role in investigating these problems and contributing in solving them. As the child is the most important element in the community, mass media aims at educating the child and the whole community about the children's right. These contribute effectively in developing the community. The study seeks for answering the following questions:

-What is the degree of parents' awareness of Jordanian child rights?

-Are there any statistically significant differences at the level ( $\propto=0.05$ ) for the degree of parent's awareness attributed to the variables (sex, kind of media ).

\section{Significance of the Study}

The significance of the study lies in the following:

1. Assuring the findings and recommendations of the conferences and the studies that aim at offering awareness about child rights.

2. Disseminating child rights awareness in the Jordanian community by the mass media.

\section{Rationale of the Study}

1. The shortage of Arab literature related the role of media in protecting the child rights.

2. The lack of research and academic studies that care about child rights,

3. Guiding and educating people of child rights by enhancing the community child right awareness .

\section{Objectives of the Study:}

The study attempts to answer the following questions:

1. What is the role of mass media in developing awareness of the right of Jordanian child?

2. What is the extent of parents' awareness of Jordanian child rights?

3. Are there any statistically significant differences at the leved $(=0.05)$ for the extent of parents' awareness attributed to gender? 


\section{Macrothink}

\section{Definitions of Terms}

The researcher used some terms used in the researcher and they were defined as follows:

Parents: The father and mother:

Mass media All the printed, visual means of media, such as, newspapers, books, booklets and maps. In addition, the audio means that include: radio, television and cinema. Radio and television are only included in this study.

Child rights: Any specific value that the law offers for the protection of child (Bani Younis ) The child : A treaty of child's rights identified the child that different nations are protecting It is any human being that does not passes the age of 18 according to the applied law in the United Nation Organization (UNISEF). This definition of the child in the national legislations is in harmony with the international treaty (2004).

\section{Literature Review}

Al Smadi (2009) conducted a study aimed at investigating the effect of media on adolescents in the governorate of Ajloun in Jordan .The findings showed that $47.9 \%$ of the participants spent 5-7 hours daily watching the media, but findings also indicated that the means of media have negative social impact such as the lack of dialogue between the children and their parents. In addition, the findings indicated positive effects represented by getting new experience and knowledge that are not available in the children's houses or schools .

Another study conducted by the directorate of developmental media in the ministry of information in cooperation with the office of the UNICEF in Damascus ( Alsmadi 2009) The study aimed to investigate the effect of radio and television in the social raising process of children. The findings showed that the children at the age of (12-16) follow radio and television programs for two or three hours daily. The percentage was $45 \%$. This indicates the bad effect of media on this certain age. In addition, the children of this age prefer to follow up the satellite channels The percentage was rapidly increasing it became $89 \%$ According to the most influential programs, the study showed that $74.9 \%$ of parents prefer news programs where sport programs took $79.7 \%$, religious programs $61.8 \%$, movies and series $58.5 \%$ and cultural programs took $53.8 \%$.

Nahed (2005) conducted also a study aimed to investigate the role of the family and social psychological guidance and media on overcoming the adolescence stop problem. To achieve the objective of the study questionnaire was designed The findings showed that the means of media have a positive role in the availability of good religious and moral education for adolescents.

Al Ayasrah (2005) conducted a study entitled "Man's rights in Holy Quran and its role in 
children human being social raising in the Jordanian community." It aims at explaining the rights of man as it is mentioned in Holy Quran and its role in children raising in the Jordanian community. That was achieved through answering six questions while reading some verses from Holy Quran To answer the seventh question of the study ,the researcher made a questionnaire consisting of (73) items delivered to the elite of thinkers, researchers in man's rights and children social raising and those concerned with the issue. They were (58).items The findings showed that God created man free to choosing his/her beliefs according to his/her thought. In addition, the Muslim has the right to express his opinions freely. The recommendation was an invitation to the educational institutions to focus on man's rights as explained by Holy Quran in all its curricula .Al Hawatmeh (2004) also conducted a study entitled "The role of media in children political raising, with Jordanian media as a typical case study .This study included the role of visual, aural and printed means of media in the political raising and the interaction among its followers. The researcher used the analytical descriptive method The findings of the study assured the role of media in raising the individuals politically that included positive and negative influence Khamakhem (2002) conducted another study in this domain entitled "Radio and Television children programs and child rights" The study aimed to know the extent of the suitability of radio and T.V children programs to Arab legislations according to child rights.The central question in AlHawatmeh study was "How did Arab legislations deal with the child's opinions and whether it guaranteed his right legally?" The findings indicated that the children's rights were legally protected.

AlHilu (2002) made a study entitled " The rights of Arab children: a model from Bahrain" The study presented in brief about the child's rights in Islam which is related to what was mentioned in the world declaration of man's rights and the treaty of child's rights In addition there was an explanation about Arab steps in Arab child's rights and such rights in the local laws in Bahrain . The researcher also assured that the child's rights are originated from the Islamic and legal understanding of such rights:

Another study conducted by AlAmayreh (2001) about" The elements of man's rights in the educational and social text books in the basic stage in Jordan and the extents of teachers' knowledge of it. The study aimed to know the extent of child caring in the basic stage the educational social text books, and the knowledge of the teachers of man's rights through a questionnaire delivered to the teachers of the basic stage in the directorate of education in Irbid. The sample consisted of (218) male and female teachers which was chosen randomly. In addition, there was a content analysis for the educational social text books for the same stage. The findings indicated that there were no statistically significant differences at the level $(\propto=0.05)$ in the extent of the teachers' knowledge of the elements of man's rights in the basic stage attributed to gender.

Abu Aheif (2000) conducted also a study entitled" Developing the Arab child's culture: perfection between culture and media and education" The study aimed to know the perfection between the culture media and the education for the Arab children through children's literature, and culture and the objectives of developing children's culture and its problems and means of 
media. The findings of the study assured the contribution of the means of media in developing the culture of Arab children.

Al Khasawneh (1997) conducted another study about the perspectives of three generations of women for the raising of child and his rights in AlNuaiymah and the effect of group variables: generation, social status, academic level, family income level, number of family and the job on such perspectives. The sample consisted of (534) women of the third generation. The findings indicated that the female three generations realize the materialist rights of children like food and health more than spiritual rights that are related to the cultural identity and self assurance.

There were no statistically significant differences at the level $(\quad \propto=0.05)$ between the mean scores of the perspectives of the three generations of women attributed to the variables: academic level, income level and job.

But the findings showed that there was statistically significant difference attributed to the social status and its interaction with generations in favor of the married ones.

In addition there is a statistically significant difference at the level ( $=\infty .05)$ attributed to the variable of family attributed favor of small families. The researcher recommended for the coordination of efforts between official and private institutions to improve the reality of child in the Jordanian environment. Finally a study conducted by Al Habashi (1996) entitled a Child's right treaty a reality and ambitions. The study presented the treaty of child's right and its objectives and Islam perspective to this treaty. The researcher assured the legal understanding to some items and objectives of the treaty.

\section{Theoretical Background}

\section{Identifying media}

Media is considered the most ancient aspect of life that accompanied the human activity since the beginning of human life on this planet. Media is still forming a form of building up relations among people and it ties individuals through culture and exchangeable effects thoughts, beliefs and different moral for all members of the community. Therefore, studying means of mass media is the studying of man's behavior and the factors and events inside and outside the community that might affect such behaviors. The American sociologist Charles identified media as " the process of transferring the meaning and the significance among individuals (2000). From the previous, media is identified as the process that is based on transferring and exchanging information between parties which might change behaviors or attitudes. 


\section{Macrothink \\ Journal of Sociological Research \\ ISSN 1948-5468 \\ 2013, Vol. 4, No.1}

\section{Child's Rights and the International Law}

Caring about children effectively began at the beginning of this century since the establishments of the international institutions when the modern international caring for child's rights began since (1924). In this year a declaration was announced consisting of five points by the international league of protecting children. This declaration was known by (Geneva Declaration)which the General Assembly for the United Nations had adapted.

Those principles (points) were as follows:

1. The child should enjoy all necessary sources to grow up in good health, physically and mentally.

2. Focusing on the necessity of providing the hungry child with food and sick one with treatment, offering the suitable caring for retarded children, rehabilitating the convicted and providing shelters for and tramps children.

3. The child has the priority in first aid and being rescued in were time.

4. The necessity for protecting the child from all ways of using him or being badly treated.

5. The child should be raised to be useful by his talents and abilities in serving the humanity.

\section{Child's Rights}

No issue has taken that good caring and estimation like child's rights. There is a full agreement that child's rights are considered a basic part of human rights which demand perfect international legislations and accepted. This was totally backed up by compulsory international treaties. Child's rights are more important than human rights because such rights cannot be abandoned in any case, it is a full duty to the responsible people It is a full responsibility since birth without being committed to pay in return.

\section{Child's Rights in Islam}

It is compulsory in Islam that parents should look after their children by providing them with the best life.

In addition, they should care about their children physically, psychologically and socially and protect them from all kinds of dangers. 


\section{Macrothink

\section{The Children's rights are clarified in the following: Child's right in having parents.}

This right is basic in Islamic religion. The child should have the caring of his parents during their life together or even after separation until he grows up and be able to look after himself.

Prophet Mohammad in Hadeeth Shareef assured on this issue by saying: "The man is responsible of his family and the woman is also responsible of her house under children (narrated by AlBukhari and Muslim) .

The children have the right to have the name of their parents. Good says: "Call the children by the names of their fathers which is the real justice" (AlAhzab :5) Therefore Islam forbid adoption while taking care of child's right in life and forbid apportion unless the cases in which the mother is threatened by death because of pregnancy (AlAnani, 1999). The children have also the right in having good names and having equal treatment whether males and females. In addition, they have the right to be well- brought up and educated (AlAnani, 1999).

\section{The Role of Radio and Television in protecting Children's Rights}

Jordanian Radio and Television Institution offered good caring for children through its programs, series and even commercials. It focused on educating children and raising them on socially, scientifically and culturally basis in order to look optimistically at life and deal with it easily. Radio and Television broadcasting always includes a good portion for children in educating the individuals about the rights of children. In addition, there is a daily coverage for official and local private activities about children where children's rights are always presented and discussed.

\section{Methods and Procedures}

\section{Method of the Study}

Human and social study could be done through different methods. In this study the historic method was included to know the development of Jordanian media. The social survey was also used for the studied phenomena. The statistic procedures were used to know the application of data and getting the percentages The social survey sample method was also used.

\section{The Population}

The families living in the governorate of Ajloun in the north of Jordan were chosen purposefully to make the researcher's work easier. 


\section{Macrothink

\section{The Sample}

It consisted of (200) families from Ajloun and they were chosen purposefully.

\section{The Instrument of the Study}

The questionnaire was prepared by the researcher. It consisted of open and closed questions. The questionnaire consisted of (18) item.

\section{Variables of the Study}

The independent variable :

1-Gender : It has two levels (male and female).

2-Child rights programs in the means of media

It has two levels (radio and television)

The variable was the extent of parents' awareness of these rights.

\section{Validity}

The instrument of the study was validated by a jury of specialists. The (18) items of the instrument were validated.

The opinions, comments and suggestions were taken into considerations and all modifications related to the language or the domain of measuring for the items were done.

\section{Reliability}

The reliability was verified by delivering the questionnaire to a pilot study consisting of (20) participants (not related to the sample). After two weeks the questionnaire was delivered again to the same sample of the pilot study and under the same conditions. The correlation was 0.78 .

\section{Statistical Analysis}

All data were analyzed by SPSS program. The means and standard deviations were used to find out the degree of the parents' awareness of the children rights T-test was also used to find the effect of gender (male, female) and the kind of media used (radio, television)and the parents' awareness of the child rights.

\section{The Findings of the Study}




\section{Macrothink}

\section{The Demographic Characteristic of the Sample of the Study}

The sample was purposeful consisted of (200) families from Ajloun governorate that represented all types of the people. It was a primary survey study.

The sample was delivered according to gender (males, females) and according to the followed means of media as shown in Table (1).

\begin{tabular}{|l|l|l|l|}
\hline Variable & & No. & Percentage \\
\hline \multirow{3}{*}{ Gender } & Males (father) & 88 & $\% 44$ \\
\cline { 2 - 4 } & Females (Mother) & 112 & $\% 56$ \\
\cline { 2 - 4 } & Total & 200 & $\% 100$ \\
\hline \multirow{2}{*}{$\begin{array}{l}\text { Followed } \\
\text { Means of } \\
\text { Media }\end{array}$} & Radio & 70 & $\% 35$ \\
\cline { 2 - 4 } & Television & 130 & $65 \%$ \\
\cline { 2 - 4 } & Total & 200 & $\% 100$ \\
\hline
\end{tabular}

Discussion of the findings related to the first question: What is the role of media in developing the awareness of Jordanian Child right?

The researcher did the means and the standard deviations for the answers of the participants for each item that related to the awareness of child rights. It is arranged from the lowest as it is shown in Table (2)

\section{Table (2)}

Means and Standard Deviations for the Answers of the Participants for each Item Related to the Awareness of child Rights

\begin{tabular}{|l|l|l|l|l|}
\hline Rank & Item & & Mear & Std. deviation \\
\hline 1 & 7 & $\begin{array}{l}\text { Protecting poor children from environment of ba } \\
\text { family. }\end{array}$ & 2.71 & 0.5981 \\
\hline 2 & 13 & Warning of dangers of addiction on children . & 2.47 & 0.53 \\
\hline 3 & 2 & Providing a clean environment for children . & 2.17 & 0.744 \\
\hline 3 & 3 & $\begin{array}{l}\text { Urging for providing health facilities for } \\
\text { children . }\end{array}$ & 2.17 & 0.744 \\
\hline 3 & 4 & $\begin{array}{l}\text { Educating people of the dangers of children } \\
\text { Work . }\end{array}$ & 2.017 & 0.744 \\
\hline 4 & 9 & $\begin{array}{l}\text { Broadcasting programs to protect children } \\
\text { from contagious diseases . }\end{array}$ & 2.049 & 0.337 \\
\hline 5 & 16 & Focusing on relarded children rights to mingle & 2.0150 .255 \\
\hline
\end{tabular}




\begin{tabular}{|l|l|l|l|l|}
\hline & & in the community. & 1.995 & 0.123 \\
\hline 6 & 6 & $\begin{array}{l}\text { Educating parents about protecting children } \\
\text { from begging . }\end{array}$ & 1.95 & 0.410 \\
\hline 7 & 14 & $\begin{array}{l}\text { Showing program to educate children about } \\
\text { car accidents . }\end{array}$ & 1.9150 .4567 \\
\hline 8 & 11 & $\begin{array}{l}\text { Educating parents about protecting children } \\
\text { from begging. }\end{array}$ & 1.87 & 0.379 \\
\hline 9 & 1 & $\begin{array}{l}\text { Encouraging children to go to school and not } \\
\text { to leave it. }\end{array}$ & 1.87 & 0.337 \\
\hline 9 & 12 & $\begin{array}{l}\text { Showing programs to educate children about } \\
\text { Car accidents. }\end{array}$ & 1.815 & 0.643 \\
\hline 10 & 8 & $\begin{array}{l}\text { Providing people of the fixed time of vaccines. } \\
\text { phowing programs to encourage children } \\
\text { participate and express their opinions. }\end{array}$ & 1.7 & 0.425 \\
\hline 11 & 10 & $\begin{array}{l}\text { Showing programs about dangers of smoking } \\
\text { to warn children. }\end{array}$ & 1.64 & 0.54 \\
\hline 13 & 15 & $\begin{array}{l}\text { Educating children about right of retarded } \\
\text { Children in prevention, health and treatment . }\end{array}$ & $\begin{array}{l}\text { Educating about protecting children of } \\
\text { Psychological and physical violence . }\end{array}$ \\
\hline 14 & 18 & 5 & $\begin{array}{l}\text { Urging for no discrimination against children accord } \\
\text { race or colour . }\end{array}$ & 0.490 \\
\hline
\end{tabular}

It is clear from this Table that number (7) got the highest mean score which was (2.71) and the standard deviation was (0.598).

Item (13) was in the second rank with the mean score of (2.475) and the standard deviation of (0.53). Items (2.3.4) came in the first rank in a mean score of (2.17) and standard deviation of (0.744), whereas item(5) came in the last rank. Its mean score was (1.215) and the standard deviation was (0.412) .

To know the effect of the sex of the parent on the awareness of the child rights, t-test was made. Table (3) shows that.

Table (3)

\begin{tabular}{|l|l|l|l|l|l|l|}
\hline Parent sex & No. & Means & $\begin{array}{l}\text { St. } \\
\text { Deviation }\end{array}$ & F- value & T. value & $\begin{array}{l}\text { Statistic } \\
\text { Ref }\end{array}$ \\
\hline Male & 88 & 1.993 & 0.170312 & 6.772162 & 2.558812 & 0.009959 \\
\hline Female & 112 & 1.920 & 0.220562 & & & \\
\hline
\end{tabular}

Table (3)indicates statistically significant differences at the level of ( $\quad=0.05)$ in the father's awareness of Jordanian child rights attributed to the sex of the parent. T. value was (2.558812) 


\section{MInstitute Macrothink $_{\text {Int }}$}

whereas f- value was (0.009) which is less than (0.05) This difference is in favor of males where the mean score was (1.993) which is higher than the mean score of the females which was (1.920)

To know the effect of the kind of the followed means of media on the father's awareness of child rights. Tests were made and shown in Table (4).

Table (4)

\begin{tabular}{|l|l|l|l|l|l|l|}
\hline $\begin{array}{l}\text { Kind of means } \\
\text { of media }\end{array}$ & No. & Means & $\begin{array}{l}\text { St. } \\
\text { Deviation }\end{array}$ & F- value & T. value & $\begin{array}{l}\text { Statistic } \\
\text { Ref }\end{array}$ \\
\hline Radio & 70 & 1.953175 & 0.752158 & 6.772162 & 0.048609 & 0.386844 \\
\hline Television & 130 & 1.951759 & & & & \\
\hline
\end{tabular}

It is evident from Table (3) that there was no effect of the followed means of media (radio, television) on developing awareness on the father about the Jordanian child rights $\mathrm{T}$. value was $(0.048609)$ and the statistic reference was $(0.386844)$ which is higher than Alpha value which is $(0.05)$.

In reference to Table (3), the findings of the study indicated that item (12) that implies "showing programs to educate children", and in discussing the percentage importance of the item between the radio and television programs for each was as explained in the previous Table.

\section{Discussion of the Findings}

It is clear from the previous findings that there was a good role le for the means of media in protecting the child rights. This was clear enough through the percentages in the findings This is in harmony with the study of AlHawatmeh(2004) which had positive and negative findings. It also goes with the study of Rida KhamaKhem (2002) which its findings indicated that the Arab legislations play a role in legal protection when applying child rights through the means of media, radio and television.

This study also is in harmony with the study of Abdullah Abu Haif (2000). The significant findings of this study are the contribution of the means of media in developing the culture of Arab children and protecting their rights.

The study also showed that there was awareness for the families of some specific rights of children. This might be due to the focus of radio and television on such rights and the desire of such families to follow up the programs about such specific child rights. Those programs call for keeping going to school and not leaving it. Those programs also urge for the availability of health facilities for children and call for providing a warm environment for children. In addition, such programs announce for taking the specific vaccines in its time and 
call for protecting children from contagious diseases.

Moreover, the programs call for protecting children from the dangers of smoking, from begging and from car accidents. Those programs also show the right of retarded and handicapped children in having health prevention and treatment, in addition to have a good life for those children of special needs.

The study also gets along with the study of Ahmad Amalyreh (2001) which has the findings of the knowledge of basic stage teachers of the principles of human rights more than other rights.

The study also is in harmony with the study of Yusra Khaswnah (1997) which has the findings of the woman's knowledge in the three generations of the materialistic, food and health rights of children more than spiritual rights that are related to the cultural identity of the children.

\section{Recommendations}

The study has come with the following recommendations:

1. Having great focus on child rights by the means of media (radio and television) to have more effect on the awareness of parents.

2. Having more focus on the role of sociologists in spreading out the child rights to parents through special programs on radio and T.V.

3. Funding and encouraging more studies and field specialized research on the awareness of child rights .

4. Meeting children in villages and rural areas in radio and television programs to know the extent of applying their rights by those who hold their responsibilities .

5. Focusing on educating the rural woman in particular the mothers.

6. Establishing special centers in villages and in rural areas for protecting child rights from abuse.

\section{References}

1. Abu Ahyaf, Abdullah (2000) Perfection between Culture, Media and Education

2. AlAnani , Hanan (1999) Child hood porter it in Islamic Religion. Ed (1)Amman :Dar Al safa' publications

3. AlHabashi, Bahiyah (1996) Child Rights Treaty, Reality and Ambition Al Fikr Al Arabi Magazine vt (17), No (83), pp 143-157

4. AlHawatmeh, Adel (2004) The Role of Media in Political Raising : Acase study - Jordanian 


\section{1) Macrothink}

Journal of Sociological Research

ISSN 1948-5468

2013, Vol. 4, No.1

Media as a Model Un published M.A The is University of Jordan Amman,

5. Al Qudah , Mohammad (1994) Television and Movie ed (1) Amman : Dar Alfikr for publications

6. Al Sall, Inshirah (1987) Child Relation with printed and ctrQnic Means Cairo: Dar Al fikr Al Arab

7. AlSammaak, Mohammad (1998) Child Right between the world legislative and Islamic Religion AlItchtihael Magazine No $(39,40)$

8. Al Smadi, Mohareb (2009) The Effect of Media of Adolecsents in Jordan . APaper presented in "youth between Reality and Ambition " Held on 22-24 march (2009) Amman National university

9. Al Hilu, wafa'(2002) Arab child Rights :A Model from Bahrain, Magazine of child and Development vl. (2) N.(7) pp(195-205)

10. Amayreh , Ahmad (2001) Principles of Men's Rights in Social Textbooks in the Basic Stage in Jordan and the Extent of Teacher's Knowledge of it Unpublished M.A. Thesis yarmouk university, Irbid : Jordan

11. Ateeqah, Najwa (1996) child Right in the International law Unpublished M.A Thesis university of Jordan Amman : Jordan

12. AlHyari, Hasan (2005) The Man's Rights in Holy Quran and its role in social raising in the Jordanian community Unpublished M.A Thesis Yarmouk University ,Irbid

13. Bain Younis, Asma' (2002) child Rights in university Documents :legislative vision Unpublished M.A Thesis university of Jordan, Amman: Jordan

14. Child Rights Committee (2004) The Third Jordanian Report : Amman,

15. Jordan Holy Quran

16. Khalil , Amani (2002) The Educational and Psychological Effect in Islamic Religion and General Child Rights Treaty (1989) Unpublished M.A Thesis yarmouk University, Irbid : Jordan

17. Khamakhem , Rida (2003) child Radio and T.V programs and child Rights Arab Radio Magazine .pp 80-86

18. mahmoud, Alia (2005). Al Madameen AlJandaryah in family and woman programs on Jordan Television.Unblished M.A Thesis . University of Jordan ,Amman-jordan

19. Mu'awad, Mohammad (1994).Child Media Cairo :Dar Al Fikr Al Arabi.

20. Nadwa,Safa'(2000).The Effect of Media in Forming the public Opinion. Unpublished M.A. This is .Aleppo University :Syria.

21. Nahed,Mohammad (2005) .The Role of the family and Social Psychological Guidance in Overcoming the Dangers of Adolescence period: An Article Al AAhar University: Al Naba' Information web.

22.Prophet's sunna (Haddeth Shareet) 